\title{
Debunking Double Bunking in the Correctional Service of Canada: A Critical Qualitative Account Jarrod 0. Shook
}

...in the context of anticipated increases in the offender population and the consequent rise in double bunking, CSC will be challenged to meet its targets with regards to the reduction of assaults and violent incidents in institutions. Everything possible will be done to provide appropriate living conditions that support rehabilitation and safe accommodation; however, double bunking is associated with adverse events. Therefore, until the additional accommodation capacity is ready, the organizations results may fall somewhat short of its targets.

- Office of the Correctional Investigator of Canada (OCI), 2011-2012 Annual Report, page 27.

$\mathrm{T}$ he above written declaration of the Correctional Service of Canada (CSC), as cited in the Annual Report of the Office of the Correctional Investigator for 2011-2012 speaks to the pervasive issue of a burgeoning federal prison population and its consequent repercussions for the correctional environment - namely, an increase in the practice of double bunking. This practice, involving the placement of two prisoners in a cell originally designed for one, has impacts on the health and safety of prisoners and CSC staff alike.

CSC is admitting that despite its goals for reducing already prevalent violence in its fifty-seven institutions, under the pressure of current legislative reforms and the inherent challenges, that the organization "may fall somewhat short of its targets". This admission, although admirable for its candid forecast, is disturbing.

As an interested stakeholder - or more crudely put, as a prisoner - in this organization's success in meeting its targets for maintaining a safe environment, this anticipated failure falls not only "somewhat short", but entirely short of any reasonable expectation for safe, secure, and humane accommodation while incarcerated. To be sure, my uneasiness, being more than a sentiment, is shared by many affected by this practice. In fact, over the last year, the Canadian penitentiary system has received extensive criticism from academics, politicians, frontline workers, and other professionals of the criminal justice nexus. Repeatedly, these authorities have expressed 
their concern about the recent penal shift to the political "right wing" under the Harper government and its 'tough-on-crime' agenda - one that is an antithesis to evidence-based policy - including legislative reforms such as the Truth in Sentencing Act (2009), the Tackling Violent Crime Act (2008), and Bill C-10, otherwise known as the Safe Streets and Communities Act (2012). Throughout the debate, the issue of double bunking has remained a steadfast talking point, as these policies are placing more of the criminalized behind bars for increasingly lengthy sentences under harsher conditions.

Among the cast of the enlightened professionals and experts voicing concerns were Howard Sapers, the Correctional Investigator of Canada, who said, "Putting two inmates in a single cell means an inevitable loss of privacy and dignity, and increases the potential for tension and violence. It is a practice that is contrary to staff and inmate safety" (OCI, 2012, p. 27). Jason Godin, President of the Ontario Region's Union of Canadian Correctional Officers (UCCO), agrees: "It creates a very unsafe environment for workers... you have tension between two inmates who are double bunked... at the same time your access to services is going to be diminished" (Paperny, 2012a).

Catherine Latimer, Executive Director of the John Howard Society, observed, "The justice system and corrections system is already under strain in this country... corrections workers and even some provincial governments are telling us there is no more room for prisoners... the Corrections and Conditional Release Act is rife with standards that can't be maintained as the numbers go up" (Brosnahan, 2012).

Kim Pate, Executive Director of the Elizabeth Fry Society, added, "Putting people in multiple person cell accommodation actually creates unnecessary stress...it's long been regarded as creating more harsh conditions than, certainly, the judge who sentenced the person ever intended" (Paperny, 2012b).

Sociologist Justin Piché advanced a cogent alternative: "We should encourage [Minister of Public Safety] Toews to seek treatment for his addiction to incarceration and put a stop to the Conservative party's 'tough on crime' agenda that is deepening the capacity crisis in our prisons" (Tibbetts, 2010).

Assuming that the above noted parties represent something of an authoritative voice on corrections, there seems to be a consensus that double bunking is a bad policy and also fails to adhere to the standards and norms set by the United Nations: 
Where sleeping accommodation is in individual cells or rooms, each prisoner shall occupy by night a cell or room by himself. If for special reasons, such as temporary overcrowding, it becomes necessary for the central prison to make an exception to this rule, it is not desirable to have two prisoners in a cell or room (UCCO, 2011, p.2).

The policy also runs contrary to the CSC prisoner accommodation policy objective, which calls for the provision of reasonable, safe, secure and humane accommodation (CSC, 2012). It is also noteworthy to mention that until February 5, 2013, the CSC recognized in principle that "single occupancy accommodation is the most desirable and correctionally [sic] appropriate method of housing offenders" (CSC, 2013). This principle belief has, however, quite recently been conveniently struck from their prisoner accommodation policy. This is not surprising for, if one were to interpret the former principle in the context of what is currently being practiced and expected to increase with rising offender counts, it would seem CSC would be placing offenders, albeit with some hesitation, not only in the least desirable, but also the most correctionally inappropriate method of housing them. Yet this, according to the Minister of Public Safety, Vic Toews, is "no big deal" (Tibbetts, 2010) and will continue despite the commitment to add an additional $2,700^{1}$ new cells to existing prison facilities which are not meant to alleviate the pressure caused by double bunking, because in the words of Toews, "Double bunking is appropriate" (Paperny, 2012b).

Having raised the issue of double bunking and fit it within the context of a controversial political agenda, met with substantial criticism from an authoritative body of frontline workers, professionals, and experts, I add my voice as a prisoner alongside this group of critics to contribute a unique perspective on the issue. This perspective deserves the title of unique for a couple of reasons. The first, as already mentioned, is that I am currently incarcerated and housed in a double bunk cell in a Canadian penitentiary, thus enabling an adversely privileged, first-hand account of that experience. Secondly, as will be demonstrated with greater precision later in this paper, this perspective has been informed with qualitative data which captured a sample of the prison population's description of the experience of sharing a cell with another prisoner in both medium- and maximum-security settings. This research was carried out with consideration of how some experts have noted that qualitative based accounts of the prison experience 
have provided rich and compelling descriptions of how prisoners cope and served to reinforce their research interests, which is an intended goal of this undertaking (Zamble and Porporino, 1988, p. 6). Interested parties that would qualify as my audience include CSC, the Minister of Public Safety, the OCI, parliamentarians, academics, the public and other interested stakeholders.

In what follows then, I intend to provide a descriptive criticism of the current era in federal corrections as it relates to the cynical outlook announced by CSC in the wake of a swelling population. It is my intent to augment this description with an up-close and personal, qualitative account of how prisoners actually experience the repercussions of such pressures, particularly the experience of having to share a cell with another prisoner.

Before embarking on this task, it is necessary to make a few more prefatory remarks. First, to hedge a bit, the point must be made that I work and write in a deprived environment. As others have found, prisoners are relatively information- and resource-deprived, with very limited access to quality reference and educational material and no access to the Internet (OCI, 2012, p. 38). It is not my intent here to excuse ignorance, but it would be appreciated if I were to be forgiven if at times this perspective appears misinformed. Second, being incarcerated carries with it the implication of having broken the law. Inherent in such a role, is the individual's onus to take responsibility for their actions. Resultantly, any criticisms levied towards CSC are made with some hesitation. This reluctance exists as it is difficult at times to separate the reality of one's position in such a situation from a critique of it. Hence, it must be qualified that although the attention here is directed outward, there are fingers pointing back that have not been overlooked and it is hoped that although having demonstrated bad character in the past, that any future right to having any good ideas has not been forfeited. Non sum quails eram. ${ }^{2}$

\section{I}

The research carried out for this paper was conducted in both the maximumsecurity environment of the former reception site for federal prisoners at Milhaven Institution (MI), as well as the medium-security environment of Collins Bay Institution (CBI). As noted, with the particular difficulties of research in prisons, design considerations can become even more complicated 
than they usually are (Zamble and Porporino, 1988, p.17). If this is true for academics commissioned to carry out research in such settings with many resources at their disposal and the support of their respective departments and institutions, then it is especially true for a prisoner seeking to carry out unofficial research in a resource-deprived environment, with only public interest and necessity as major allies. Nonetheless, I sought to overcome these obstacles and balance out the needs of the research project (i.e. gathering qualitative data on the experience of double bunking) with the amount of resources available. It is perhaps worth recognizing that as a participant observer in the study setting, I was in the unenviable position of having full access to the prison population without the hindrance of bureaucracy or other limiting security protocols that are typical with research in prisons. Nevertheless, this freedom demanded that ethical considerations remain paramount and every step of the design process and the study itself was executed with the unyielding standard that no harm was to come to any of the participants.

All respondents in the study were voluntary participants who were informed of the nature of the research and verbally granted their informed consent to participate. It was a goal of this project that 10 prisoners who were double bunked in each setting be approached for agreement to participate in a study that sought to gather data on their experience of sharing a cell with another prisoner in order to report their responses in a research paper. Although it would have been preferable that the individuals selected to participate in the research project be random, this was a difficult standard to achieve. Thus, as a participant observer in the population being selected for the study, insider information was available that made it possible to approach only those people who were double bunked, which was nearly 100 per cent of the population in the maximum-security setting and 20 per cent in the medium-security setting. This method of sampling, "reliance on available subjects", is identified in the academy as being an inadequate sampling method (Babbie, 1995, p. 26). However, this non-probability sampling method was unavoidable, as it would have been impossible, given the circumstances, to use other options. It is noteworthy to mention, however, that although the prison population on the whole is heterogeneous in age, ethnicity and individual backgrounds, the homogeneity of the population relevant to the substantive interests of the study from which the sample was drawn (i.e. all male prisoners in a double-bunk cell accommodation) enhanced the representative value of the sample. 
The reliability of the method was also a priority. Therefore other imperative considerations that were given to this relatively standard research practice included making sure that the open-ended survey question was clear enough to the respondents to yield clear answers. As previously noted, the meaning of one's response to a question has much to do with the wording (Babbie, 1995). The term "double bunking" tends to carry a negative connotation as far as terminology is concerned; therefore to resolve this, the question was posed as follows in order to ensure reliability and to avoid encouraging the respondent to answer in a particular way: "Please describe your experience of sharing a cell with another inmate (double bunking)". Balancing out the question with the inclusion of "sharing a cell with another inmate" seemed pertinent to negotiate the subtle differences in response that might be expected.

The open-ended question was self-administered, which was appropriate to the setting and the goals of the project. This methodology ensured that the individual respondent would be given time to give consideration to the question and at the same time have a degree of control over the conditions under which they would answer the question, (i.e. in their cell). One limitation considered in relation to this method was the fact that the individuals would be responsible for responding to the question and returning their responses the following day. This meant they could potentially forget about it or procrastinate. Ultimately, the response rate was 80 per cent.

The first consideration given before approaching a prisoner to request his participation, which ultimately turned out to be ethical, as well as an indicator of reliability, was whether or not the respondent was competent enough to answer the question posed in the survey. This is especially relevant to a prison population, where literacy levels tend to be much lower than in the general population. With this in mind, it was with a certain degree of caution that individuals were approached. For instance, in one case an individual was approached who initially seemed quite interested in the project. However, once he found out that the research design called for the response to be selfadministered, he abruptly declined to participate. A short while later the same individual approached me to apologize for his refusal to participate, stating that he did not have the ability to read or write. This was a sobering moment for me, and from then on, it was recognized that simply requesting participation in the project carried with it the latent consequence of causing a potential respondent to face aspects of himself that he might not normally be inclined to consider. 
This was also an ethical consideration that was given when bearing in mind the fact that the very act of requesting a prisoner to describe their experience of sharing a cell with another prisoner could lead them to become more conscious of that experience and cause them further distress in an already distressful environment. Ultimately, when balanced against the ends of the project it was determined that this was also an unavoidable possibility.

As identified, the research carried out for the purposes of this paper was conducted in both the maximum-security environment of the former reception site for federal prisoners at Milhaven Institution, along with the medium-security environment of Collins Bay Institution. Before reporting the data, I will provide descriptions of these two settings in order to contextualize the findings presented thereafter.

\section{Milhaven Assessment Unit}

Milhaven Assessment Unit (MAU) was the former reception site for all federal prisoners in CSC's Ontario Region sentenced to two years or more. In the wake of a planned prison closure for Kingston Penitentiary (KP), the Assessment Unit has been relocated to Joyceville Institution, as the Milhaven site and its cell space is refitted to accommodate the flow of maximum-security prisoners due to arrive with that closure. Although part of this study took place while MAU was still operational, as of December 2012, no new prisoners were to be received at Milhaven for reception.

Reception into federal custody is carried out through a process that ensures CSC authorities may review the cases of all new admissions to determine their individual needs and make decisions on which penitentiary to place them. The stated purposes of this process are to ensure that all prisoners entering the federal correctional system a) undergo a full assessment of their program and security needs, b) are provided with counselling to help them adapt to the penitentiary environment, c) are informed of such matters as program opportunities, rules, and regulations about conduct and the prisoner grievance process, as well as d) that they have a correctional plan designed to address their individual needs. ${ }^{3}$

All male offenders go through the above noted operations (as targets of information) before moving to their penitentiary placement, informally 
referred to as a "Mother Institution". ${ }^{4}$ Federal institutions fall into three categorized security levels: maximum, medium and minimum. The Milhaven Assessment Unit, being housed within the notorious Milhaven maximum-security institution, thus operated under a maximum-security regime. Under this regime, in addition to extracting information on the life histories of their residents, CSC promised to a) make sure that all prisoners are clothed and fed, b) that they are provided with proper bedding, c) that they are given toilet articles to stay clean, and d) that they are given the opportunity for at least one hour of exercise per day. To accomplish this task within the parameters of a maximum-security environment, a particular operational routine had been devised. Consequent to the maximum security dictate, the MAU routine required that all prisoners remain locked inside their cells for 23 out of 24 hours a day, aside from 25 minutes that were allotted for a shower and telephone call every other day. To be fair, as part of the assessment process, prisoners would at various times be required to leave their cells for appointments with parole officers and other decision makers. Additionally, there were institutional work assignments that were offered to MAU prisoners. However, these positions were scarce and only offered to a select group who met the security criteria. Thus, it is fair to say that a majority of prisoners were expected to spend a majority of their time inside their cells. As intolerable as this may sound, the cell accommodation at MAU was for double bunking, which has been identified as most pervasive in the CSC assessment units with occupancy rates exceeding 160 per cent in some penitentiaries (OCI, 2012, p. 24).

The cells at MAU were five square metre wet cells, equipped with both a toilet and a basin. Although it did not appear that the cells were designed for the purposes of holding two prisoners, there were two bunks. It would seem that this was not intended as a permanent accommodation as in many of the cells the top bunk had been retrofitted with a chain and contained no accessory to accommodate the climb to the top. Each cell was equipped with a barred window that allowed some natural light to flow into the tiny space and could be opened and closed at the leisure of the occupants. In addition to the natural light, each cell was also equipped with a $32 \mathrm{~W}$ fluorescent light. There were two electrical outlets for the use of prisoners who possessed electronics, such as a television set. At one point, MAU issued "range" televisions, which were to be loaned to arriving prisoners for use in their cells the duration of their stay (anywhere from 36 months on average). Television, although a luxury by some standards, would allow prisoners to 
watch cable television and were paid for out of a prisoner-funded account. At the time of my arrival at MAU, the remaining television sets had been routinely retracted. However, any prisoner who had the means, could send in their own from the community. Although I was unable to identify exactly how many cells did or did not have a television, I observed many without one. This obviously created some additional tension and discomfort for those who were unlucky enough to be housed together without the means of obtaining one. As this picture illustrates, the conditions of confinement were relatively harsh and exacerbated by the fact that two prisoners had to share such a small and deprived space with one another.

\section{Collins Bay Institution}

Collins Bay is one of five medium-security institutions in the Ontario Region. Optically from the exterior, Collins Bay holds a shadowy image, with its large walls and archaic structure, including castle-like guarded gun towers. This image, although representative of the spirit of the institution, in no way compares with the more modern, technologically advanced, and aesthetically pleasing interior. This medium-security institution is divided between an onsite medical health centre, cafeteria-style mess hall, programs building, recreation centre and outdoor track, as well as five security units for cell accommodation labelled 4, 6, 7, 8, and 9 block respectively. In likeness to MAU as far as prisons go, but in its own manner of containment, Collins Bay Institution also administers its own particular security dictate. Although in a technical sense "a medium is a medium is a medium", Collins Bay would be a de facto high-medium, compared with the other, more liberal security dictates of medium-security institutions found throughout Ontario like Fenbrook Institution or Bath Institution.

In effect, Collins Bay could also be considered a quasi multi-level complex. If this is true now with the division of security that exists within the prison itself between 4 block (high), 6,7, and 8 block (medium), and 9 block (low), it will be especially true once the maximum-security unit currently being constructed is complete and operational.

As with other institutions, particularly medium security, under the pressure of current legislative reforms, Collins Bay has resorted to the practice of double bunking in an effort to manage these pressures and currently operates at the 20 per cent double bunking maximum of 86 cells as per its population. These double bunks are uniformly spread throughout the institution in each block. 
Of the five security units, 4 block is considered to be from the "old school", and this is true both literally and figuratively. The 4 block security unit is what remains of the original architecture for cell accommodation at Collins Bay. Generally, placement at 4 block is seen to reflect one's position as a greater threat to the safety and security of the institution, and is also seen as less desirable for cell accommodation. Nonetheless, as with other security units of the prison, cell accommodation at 4 block has also been revised to include double bunking.

The cells in 4 block are below the regulation standard for dual occupancy, as outlined in Commissioner's Directive 550 for prisoner accommodation, and, as with the cells at Milhaven, are "wet" cells containing a sink and toilet. Additionally, these cells contain a window that allows some natural light to flow into the cell, which can also be opened and closed at the leisure of the occupants.

As a unit, 4 block contains showers and telephones, as well as laundry facilities. Operation is on the same schedule as the rest of the facility and the unit opens up into the mess hall three times daily for meals, at 7:30am, $12: 00 \mathrm{pm}$, and 5:00pm. As in other units, if a prisoner does not attend work, school, or any other program being offered during the day, he is expected to remain locked in his cell, aside from a short break in the morning and afternoon, during which cells open up to facilitate the return of prisoners coming back from their work assignments. Nonetheless, during daytime hours many prisoners, especially those who are double bunked (particularly newcomers), must remain locked in their cells. ${ }^{5}$

The new units 6,7 , and 8 , which were built on the principle of direct observation, contain 8 ranges with 12 cells on each range, which on the top tier of each building contain 5 double bunks, for a total of 20 double bunks per unit. As mentioned, this meets the exact cut-off that has been adopted as a formula for the capacity of double bunking, which is 20 per cent in each region. Therefore, at 86 double-bunk cells, Collins Bay is at the threshold but in compliance.

Unlike the cells in 4 block, the new units of 6, 7, and 8 block are much larger, at the regulation standard of seven square metres. These newer cells are also wet cells containing a window with natural light, as well as numerous electrical outlets for electronics and shelf space for personal belongings. Unlike Milhaven, CBI prisoners are considered penitentiary placed and are therefore entitled to have up to $\$ 1,500$ in cell effects, which must be sent in at their own cost within the first 30 days of their arrival 
and are for use the duration of their sentences, provided these items meet the security criteria. Cell effects that are allowed include television sets, clothing and gym equipment.

Also unlike MAU, the security schedule is more liberal, and although prisoners who do not attend work, school, or other programs during the day are locked up except for meals, from 6:00pm to $10: 30 \mathrm{pm}$ each night and during day hours on the weekends, all cells open up for general association in the recreation yard.

Recreation, which operates on an hourly change-over to and from the yard, includes clubs rooms, a billiards room, an outdoor track and weight pit, as well as an indoor basketball court and gym. Certainly the CBI environment, particularly after 6:00pm, offers much more freedom than MAU.

In keeping with the multi-level philosophy, CBI also includes a "special" unit called 9 block. In 9 block the ranges are more or less self-contained living units with full kitchens and showers. In this block, as a privilege for good behaviour and the appropriate custodial scores, a prisoner is entitled to prepare his own food on a budget he must keep for himself of $\$ 4.75$ per day.

Thus, in comparison with MAU, CBI is in a class of its own in relation to the conditions of confinement. This is an important distinction that must be made when bearing in mind the responses that were given as prisoners described their experience of sharing a cell with another person. Nonetheless, as will be demonstrated, the differences of attitude towards the experience are often quite similar.

\section{III}

This study was born out of a union between experience and education on the practice of double bunking. Thus, it was not with neutrality that the research was initiated, but rather out of the necessity to draw attention to the fact that it was a damaging experience. As such, it was expected that the responses gathered in the study would reflect this assertion, though to what degree it was difficult to accurately surmise without systematically consulting those who must negotiate that experience. Furthermore, the study here was never intended to be an exhaustive exploration, but rather to stimulate further research into the issue by more powerful actors on the stage of national policy.

It was expected that the data gathered would lend confirmation to some previously published critical analyses of the situation. This was established, 
and in the pool of public voices weighing in on the issue, the Correctional Investigator, Howard Sapers, seems to have been one of the most coherent, when the data gathered here is weighed against comments promulgated by him in his most recent report to parliament in the Annual Report of the Office of the Correctional Investigator 2011-2012:

Prison crowding has negative impacts on the system's ability 10 provide humane, safe, and secure custody. Putting Iwo inmates in a single cell means an inevitable loss of privacy and dignity, and increases the potential for tension and violence. It is a practice that is contrary to staff and inmate safely. Crowding is linked to higher incidents of violence, prison volatility and unrest, as well as the spread of infectious diseases (p. 25).

By unpacking the Correctional Investigator's statement, and synthesising the data gathered in this study, we can begin to construct a poignant, coherent description of double bunking as seen through the eyes of those who must endure it. As observed, double bunking impacts the system's ability to provide, humane, safe and secure custody. This is an erosion of the policy objective of the Commissioners Directive for cell accommodation and defies the fundamental mission of the Correctional Service of Canada (Mission and Core Values). To verify, one respondent in the study succinctly offered his orientation towards double bunking, "It's unhunane [sic] some people can't handle it straight up" (MAU). ${ }^{6}$ While another, perhaps a little more versed on international standards stated, "Other than factually being inhumane and against the Geneva Convention, it does very little to help in the rehabilitation process" (MAU). While still another identified how quite literally the experience of sharing a cell with another person has actually served to quash his humanity:

After I started noticing a pattern with the cellmates I have not gotten along with I found that if I became completely neutral with everyone I came across I wouldn't be bothered by their actions, well most of them, and I could be 'comfortable' in any and every situation... This numbness and neutrality is the hardening of individuals people speak of and is really counterproductive (MAU).

This reference to hardness is not surprising when prisoners under such conditions simply do not feel safe such as one respondent starkly stated: 
'I'm more violent and intolerant than I've ever been mainly because here its sheep or wolf and I refuse to be eaten" (MAU). While another respondent offered a similar assessment stating, "The cell is a place where we are to feel comfortable and secure when you double bunk you lose that and the result will ultimately end up in violence" (CBI). Substantiating this suggestion another prisoner poignantly stated the following:

Sharing a cell is no good for most people. Myself I find it hard to live with people when I'm in my everyday life on the outside. In here I'm finding it harder I feel like smashing and slicing my cellmate and I don't think like that in everyday life (CBI).

Notably, even staff at the medium security prison Warkworth filed a complaint under the labour code, arguing that double bunking had put them in danger (CBC News, 2011). If guards do not feel safe under such conditions, why should a prisoner?

Further to the contradictory nature of the practice of double bunking in relation to existing policy calling for safe, secure, and humane custody, the Correctional Investigator also identified the fact that double bunking means an inevitable loss of privacy and dignity. Predictably, if you consider the structural features of the cell in which the respondents were confined, one prisoner confirmed this fact by analogising his experience with the metaphor of being locked in a bathroom:

...the only way I could describe this to a average person is imagine locking yourself in a average size bathroom for a few months with another man no privacy for using toilet and highlight of the day is getting to go run out back in the kennel for an hour and a half (MAU).

While another prisoner maintained that, "I would have to start by saying that having to share a box the size of a bathroom, with another man, has been the most degrading experience of my life" (MAU).

The above statements being synonymous with the declaration that putting two prisoners in one cell means an inevitable loss of privacy and dignity sheds light on the essential need for human beings in any situation to have some privacy, let alone in a prison environment. Yet, as one prisoner under these conditions recognizes, "The need for personal space and time alone is 
completely disregarded by CSC" (MAU). Still another respondent observed, "It's so hard to be crammed up in such a small area for anybody" (MAU). As it became apparent, this is especially so during times of personal distress:

Forget about having any alone time. If you're given bad news from the street, or if stress levels go up alone time is no more. So there's always a sense of anger at the system for letting this happen to grown men (MAU).

Perhaps most people take for granted their right to physical privacy from day to day, and if this is true for those moments when almost anyone would require some solitude, including in moments of personal distress, it is especially true for such things as using the washroom or getting changed. The following statements therefore indicate how the experience of sharing a cell that doubles as a living quarters and a bathroom actually impacts upon a prisoner's individual dignity: "Having to go to the washroom with another person only feet away is disgusting, unhygienic, and did I mention gross" (MAU). Another prisoner related that, "I hate having to shit in front of someone and having to be in the cell when someone else is" (CBI). While another prisoner conveyed, "Anytime the inmate has to go to the bathroom for a bowel movement. Every time you have to go, your dignity level drops a few notches" (CBI). Certainly, too, there are other more thwarting potential drawbacks to having very limited privacy and space as voiced by one respondent who bluntly stated, "the worst part is the farting and not being able to jerk off in peace" (MAU).

Likewise, living in such close quarters is unhygienic and can also contribute to the spread of infectious diseases, which affect the prison population at an exceedingly disproportionate rate compared to the general population. One respondent recognized this with the following statement:

Double bunking is a headache because your cell mate may do certain things that make you upset, for example: using the bathroom while you were sleeping, brushing his teeth, not cleaning the toilet, not cleaning the cell. It's hard when a person stinks, and doesn't clean himself or his clothes on a regular basis $(\mathrm{CBI})$.

Naturally, if such a word is fitting to describe such an unnatural environment, the implications of such conditions of confinement and assaults on individual dignity, as the Correctional Investigator observed, 
also increases the potential for tension and violence. In his words, "It is a practice that is contrary to staff and inmate safely" (OCI, 2012). For instance, as one respondent remarked, "Everyone should have a place to go for solitude [and] privacy. Without that it causes tension in their life. That tension has no place in the cell" (CBI). Still, another respondent stated:

...no matter how many interests you have in common with someone, when you're in a cage this small for long enough good relationships turn sour and sometimes violent.. No 2 people are alike enough to withstand this and thus end up walking or wailing on each other (MAU).

The above account is no exaggeration and corresponds with recent data released by the Correctional Investigator which cite the fact that CSC reported 1,248 prisoner assaults and fights in 2011-2012, an increase approaching 33 per cent over a four-year period (OCI, 2012, p. 25). This is a trend that seems obvious to some prisoners, such as one respondent who declared, "No wonder prison violence has gone up. My experience of sharing a cell with another inmate is very unpleasant" (CBI). Another maintained, "Sharing a cell with another inmate in prison is an unpleasant experience. Spending the majority of the day in a cell with another person is frustrating and definitely could lead into a violent situation" (CBI). This was again reiterated by one prisoner who shared the following:

Myself I'd almost rather be in the hole then have a cellmate. I have a hard time sleeping and I get meds for that I still wake up at night from time to time while I'm on my meds the meds help me go right back to sleep instead of staying awake. Having a cellmate he keeps me awake at all hours of the night and what not we have had an argument and he accused me of being racist. This double bunking is causing fights that would otherwise not happen it's no good build more units within the institutions. (CBI).

The fact is that double bunking does make for a volatile environment. Quite literally, one prisoner described the explosive nature of being placed under such conditions:

No one likes being told what to do, and most people do, and most people don't enjoy having to tell someone else what to do so they remain 
comfortable. Most people are stuck somewhere in the middle second guessing themselves, or worse, holding all that spite and anger inside. A lot of people inside are literal time bombs waiting to go off and it's no wonder after having to learn to adapt to such conditions people get out and re-offend or develop excessive habits, unhealthy relationships, and/or mental problems (MAU).

This estimation was confirmed by another respondent who stated:

I have had some cellies that I have hated and this has put me in some very bad spots. Because it is very hard to ask another person to leave. Or if he was in the cell first, it's even harder. But if people are like me, then we just let things build up. Then when we can't take it anymore, that's when someone gets hurt (CBI).

What is more is the fact that it is not only independent observers and the prisoners themselves that identify the volatility of the modern correctional environment. CSC as an organization is in fact quite vocal about the challenges that they face in carrying out their mandate as a portion of the following report details:

Complex challenges in CSC's operating environment creates pressures and demands related to an offender population with more extensive histories of violence and violent crimes; previous youth and adult convictions; affiliations with gangs and organized crime; higher rates of infection of Hepatitis C and Human Immunodeficiency virus (HIV); a disproportionate representation of First Nations, Metis, and Inuit offenders; Serious substance abuse histories and related problems; and serious mental health disorders (CSC, 2012, p. 3).

Yet, in considering these "complex challenges" it is difficult to fathom how it is that compounding the situation by placing two "complex" prisoners in a cell designed for one seems reasonable. To answer this, CSC has begun implementing a Shared Accommodation Assessment (SAA) that per Commissioner's Directive 550 seeks to "screen offenders against a number of criteria including compatibility, vulnerability, and predatory or permissive behaviour to determine suitability for double occupancy" 
(OCI, 2012, p.27). Although, as the OCI found, in a number of occasions the procedures for assessing personal suitability and compatibility have at times been found to be incomplete, inappropriate and or lacking in proper documentation, and in one case resulted in a homicide (OCI, 2012, p.27). When all of the responses were gathered together, compatibility emerged as a theme as the following comments illustrate:

It's tough when you have to live in such close proximity with other peoples habits. What I try to keep in mind is that someone else is having to live with mine. Some people I get along with better than others. I've strengthened some friendships and I've ruined others. I guess it really depends on who a person is bunked up with. I have a touch of OCD so I can get pretty irritated over small things. I try to stay cognizant of that because these are my issues and not someone else s but sometimes I can get pretty annoyed (CBI).

With me being antisocial and not liking people too much I have to say that I have been extremely lucky to have had cellmates who are compatible to my lifestyle and interests and the fact that I've met them before helps too. I find that if you are a positive altitude kind of guy it rubs off on a cellmate and the experience is better (MAU).

In the aspect of having company from time to time it's okay, if your compatible that is. But just like any person to person relationship spending $100 \%$ of all your time with one individual things can go sour really quick (MAU).

Sometimes it's ok because you've got somebody to talk to, but everyone's got their flaws and annoying habits so it's also very hard sometimes especially when you are locked up with the person for most of the day! It's even harder if you and the other person are not compatible! But in my eyes nobody should be double bunked. It's better for privacy and it would cause less issues among inmates! (MAU)

Ultimately, in addition to the potential for violence and other disturbances, the practice of double bunking tends to turn the correctional system away from its intended purpose as a place of rehabilitation into something quite 
different. Perhaps this is what the Union of Canadian Correctional Officers was referring to when they indicated the following in their Critical Review of the Practice of Double Bunking Within Corrections (UCCO, 2011, p. 14): "Should the overcrowding of Canadian correctional facilities continue, the days of rehabilitating and re-socializing offenders will disappear". One respondent in this study agreed with this position:

Being forced to listen to another element of criminality; the persons story; their level of eagerness to change, all affects my personal quest to change for the better. Adapting to that element is not beneficial to criminal, or society in general (MAU).

Citing recent academic research, UCCO $(2011$, p. 6) argues that "For many offenders, this type of environment may in fact prove to be criminogenic, effectively resulting in offenders being released into the public who have the same, if not greater, propensity towards crime when they were first admitted".

Inevitably, as you increase the population of a penitentiary there is also a concomitant impact on the infrastructure of the prison, which becomes pressured to do more with less. These impacts are felt at every corner of the prison from the cell itself, access to programs, health care/mental health, education, vocational jobs, and also on the case management team's ability to handle their caseloads. ${ }^{7}$ Professor Allan Manson, whose academic work specialises in prisons, made the point in a recent documentary on Kingston Penitentiary: "You can pop 100 new cells... What about health care? What about food? What about visits?" (Spence, 2012).

In the case of double bunking prisoners recognize this first and foremost in their cell space: "The storage space is far too limited to house two peoples' belongings" (CBI). Another prisoner stated:

Also the Collins Bay double bunking cells are a joke because it's designed for a single cell all they did was add a bunk on top with the light directly in your face at least they could adjust it to the centre of the cell. They're not enough shelves, hooks, like at least if you're going to put in a bunk use your common sense and add shelves and hooks. Unbelievable (CBI).

Beyond the physical space of the cell, the waitlists for access to programs also get longer. The position of the Office of the Correctional Investigator, 
which is in line with available evidence, is that: "inmates should be actively engaged in programming... as soon as practicable after admission, regardless of sentence length, security level, or parole eligibility" (OCI, 2012 p. 37). Yet, as the Correctional Service of Canada goes through its largest physical expansion in cell stock ever, it is also managing a 295 million dollar reduction in its operational budget impacting programs, services and supports for offenders (OCI, 2012, p. 43) ${ }^{8}$ Although not quantifiable by my limited resources, it is an observation that an exceptional amount of prisoners are waiting even longer to enter their correctional programs, while an even greater amount compete for scarce work assignments offered throughout the institution. This shows how the focus no longer seems to be corrective and, as the UCCO (2011) warned, CSC now seems to be warehousing prisoners until they are released back into the community (OCI, 2012, p. 14). On this point, one prisoner observed, "We are warehoused here and basically forgot about" (MAU), which as recent evidence seems to show can also be a breeding ground for gang growth and recruitment. The Correctional Investigator confirmed this in an interview with Evan Solomon on the program Power \& Politics, stating that it is not surprising when there are "not a lot of other things to do". Supporting this argument is the fact that gang memberships have, according to the most recent data available to the public, risen by 44 per cent over a five-year period (Solomon, 2012a).

Yet, peculiarly, the divestment of correctional programs seems to have corresponded with the investment of security programs such as the 250 intelligence gatherers hired throughout the 57 institutions that CSC manages (Solomon, 2012a). Meanwhile, all part-time chaplaincy staff have been given pink slips beginning this fiscal year, leaving only the 81 fulltime chaplains, eighty of which are Christian, to deliver spiritual services to a complex and diverse population (Solomon, 2012b).

It is hard to understand how it is justifiable to diminish programs and supports for offenders while making the environment harsher and more restrictive. Logically, one would expect that prisoners would be in even greater need under such conditions and quite possibly even more receptive to these interventions during such large-scale change. Yet, as the experiences captured here shows, a state of anomie is being manufactured:

This experience is degrading demoralizing and has no rehabilitative qualities at all. It makes you into an angry and pessimistic person it 
changes you for the worse and being a recidivist proves how hard it is to change what this place turns you into (MAU).

The responses gathered here all seem to reflect a common element of environmental determinism. To quote the political activist and writer George Jackson (1970, p. 19): “To determine how men will behave once they enter the prison it is of first importance to know that prison. Men are brutalized by their environment - not the reverse". This is an important consideration to keep in mind especially as the Conservative government ploughs forward with their 'tough-on-crime' agenda despite all of the available evidence from CSC as an organization, the frontline workforce, the academic research community, and statistical findings promulgated by the federally appointed correctional investigator that demonstrates the inherently damaging nature of the practice of double bunking. It is hoped that if there is any validity to be found in the critical outlook maintained by these parties that the experiences captured in this small study will provide some essential nuance to the fray.

There is no doubt that it is an easier task to identify those aspects of the system that are faulty than it is to propose solutions to those problems. This is especially so in the correctional system, where at the end of the day it must be recognized that CSC is responsible for respecting the sentencing decisions handed down through the judicial system. However, in the words of Kim Pate of the Canadian Association of Elizabeth Fry Societies, "Putting people in multiple-person cell accommodation actually creates unnecessary stress It's long been regarded as creating more harsh conditions than, certainly, the judge who sentenced the person ever intended" (Paperny, 2012b). The fact is, that double bunking, with its ubiquitously nefarious influence on the prison environment is fundamental to the difficulties that the Correctional Service of Canada faces in carrying out its mandate.

\section{ENDNOTES}

1 This figure must be interpreted with caution. CSC is also closing three prisons Kingston Penitentiary, the Regional Treatment Centre in the Ontario Region and Leclerc Institution - at a loss of approximately 1,000 beds.

2 "I am not what I once was" is from the title of Ernest Dowson's $19^{\text {th }}$ Century poem. As outlined in the handbook given to newly admitted prisoners.

A mother institution is the initial penitentiary placement for an individual. It is the 
institution that an individual would normally be returned to if he or she violates their parole conditions.

5 New arrivals often spend more time in their cells as a result of their low seniority for work assignments or programming.

6 MAU denotes confinement at Milhaven. CBI refers to Collins Bay. Spelling has been adjusted in the interests of facilitating reading.

7 Each prisoner is assigned to a case management team consisting of a Parole Officer and a COIL (Frontline Correctional Officer) who will manage the case and complete relevant paperwork for decision-making purposes.

8 Part of the deficit reduction action plan (DRAP).

\section{REFERENCES}

Babbie, Earl (1995) The Practice of Social Research, New York: Wadsworth.

Brosnahen, Maureen (2012) "Record high prison numbers sparking violence" $C B C$ News

- August 27. Retrieved from <http://www.cbc.ca/news/canada/story/2012/08/27/prisonnumbers-crowding.html $>$.

CBC News (2011) "Prison double-bunking used in segregation cells" - November 22. Retrieved from < http://www.cbc.ca/news/canada/story/2011/11/22/doubledunking-csc.html>.

Correctional Service of Canada (2013) Commissioners Directive 550: Inmate Accommodation, Ottawa - February 5

Correctional Service of Canada (2012) Report on Plans and Priorities 2012-2013, Ottawa.

Jackson, George (1970) Soledad Brother, New York: Coward-McCann.

Office of the Correctional Investigator (2012) Annual Report of the Office of the Correctional Investigator 2011-2012, Ottawa.

Paperny, Anna Mehler (2012a) "As prisons close, complaints of overcrowding rise", Globe and Mail - May 9.

Paperny, Anna Mehler (2012b) "Double bunking in crowded prison cells is not a problem for Toews", Globe and Mail - July 11.

Solomon, Evan [Host]. (2012a). Power and Politics [Television Broadcast], CBC News - October 24.

Solomon, Evan [Host]. (2012b). Power and Politics [Television Broadcast], CBC News - October 5.

Spence, D. [Producer] (2012, December 9). Held Hostage [Television Broadcast], Toronto: CDC, December 9.

Tibbets, Janice (2010) "Minister downplays prison double-bunking", National PostMay 4.

Union of Canadian Correctional Officers (2011) A Critical Review Of The Practice Of Double Bunking Within Corrections: The Implications On Staff, Inmates, Correctional Facilities and the Public, Ottawa.

Zamble, Edward and Frank J. Porporino (1988) Coping Behaviour and Adaplation in Prison Inmates, Kingston (ON): Queen's University. 


\title{
ABOUT THE AUTHOR
}

Jarrod O. Shook is a prisoner at Collins Bay Institution where he is serving a seven-year sentence. A former university student who plans to continue his education upon release, he can be contacted at:

\author{
Jarrod Shook, FPS 892083E \\ Collins Bay Institution \\ 1455 Bath Road \\ P.O. Box 5117 \\ Kingston, Ontario, Canada \\ K7L 0A8
}

